
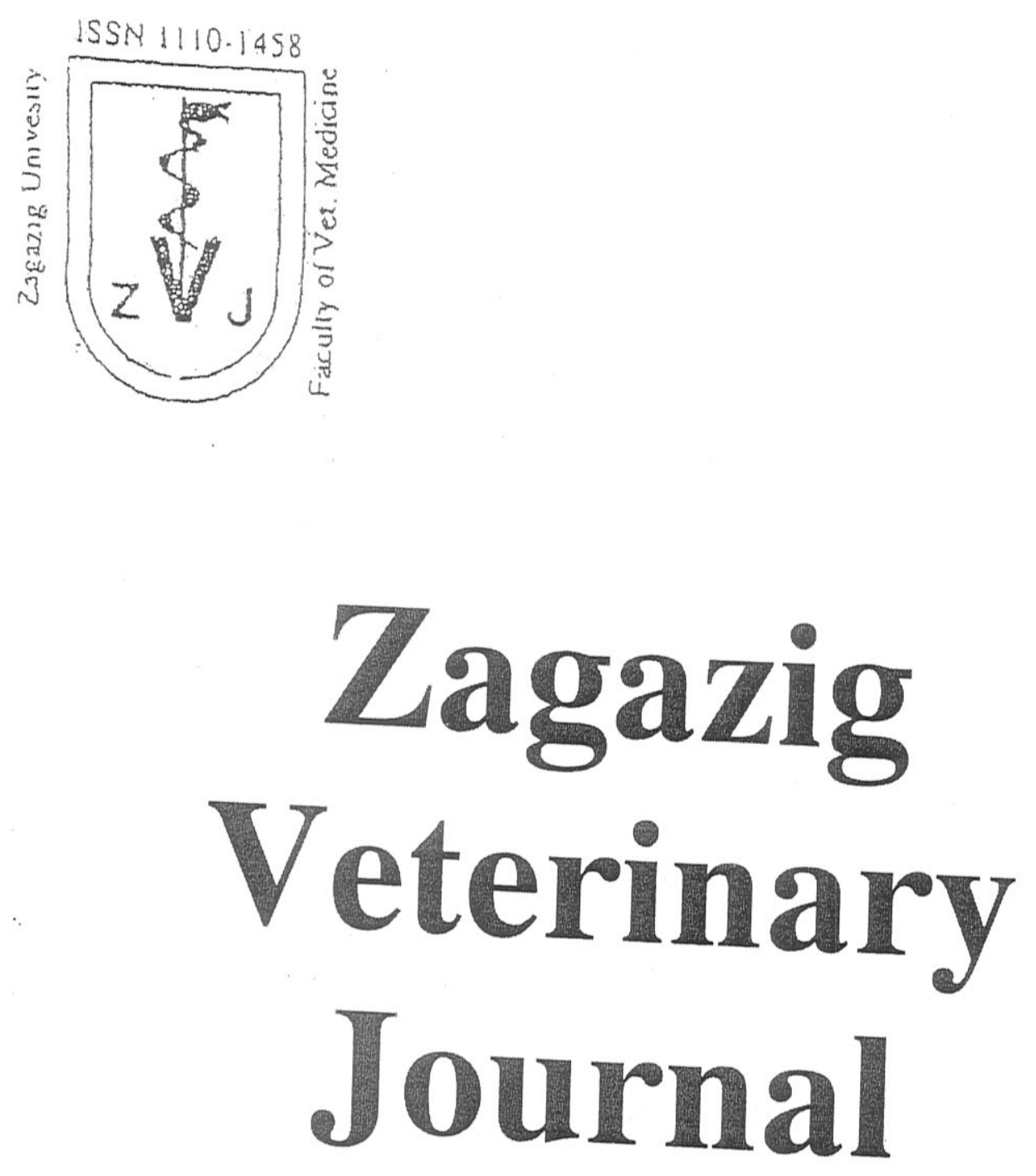

Volume : 41

Number: 2 



\section{Zagazig Veterinary Journal}

\section{Chairman of Administrative Board}

Prof. Dr. Mahdy Abd El-Gwad Abd El-Kader, Dean of Faculty of Veterinary Medicine

\section{Vice Chairman}

Prof. Dr. Fathy Dosoky El Seddawy, Vice Dean for Postgraduate Studies and Research Affairs.

\section{Chief Editor}

Prof. Dr. Nariman M. M. Edrees, Department of Clinical Pathology.

\section{Treasurer}

Prof. Dr. Ahmed M. El-Sadek Hegazy, Department of Poultry.

\section{Editorial Board}

Prof. Dr. Mohamed Said M.M. Nada

Prof. Dr. Hamed M. Nosseur

Prof. Dr. Mohamed H. Bareedy
Prof. Dr. Magda A. Amin

Prof. Dr. Mohamed Tayiser Samy

Prof. Dr. Magdy E. H. El-kholy 

Zag. Vet. Journal (ISSN, 1110-1458)

Volume 41

Number 2

2013

\section{CONTENTS}

1 PCR-based Differentiation Of Zoonotic Fascioliasis

Adel M Abdel-Aziz Newishy

2 Immunological And Biochemical Changes In Draft Horses Naturally Infested With Gastrointestinal Nematodes With Trail of Treatment With Fenbendazole In Sharkia Governorate

Nasr, SS, Neesren A Shawky Aly Salah, ABS and Hussen E M.

3 A Trial For Developing Of Inactivated Pneumo-4 Vaccine By Using of An Immunostimulatory Complex (ISCOM)

Abdel-Hady MK, Ghattas WM and Abd El-Razek BA

4 Effects Of Dietary Application Of Two Antagonistic Gut-Isolated Bacillus Species On The Immune Response Of Oreochromis niloticus To Aeromonas hydrophila Infection

El-Bouhy ZM, El-Nobi GA, Hassanin ME and El-Hady MA

5 Effect of Propolis, Florfenicol, And Their Combination On Catfish (Clariaz Lazera) Experimentally Infected With Aeromonas hydrophila

Sawsan M A El-Sheikh, Hosny A E Ibrahim, Refaat K Mohamed and Dalia I M Ibrahim

6 Clinicopathological Studies on Effect of Doxorubicin Hydrochloride on Heart of Rats

Amany A M Abd-Allah and Hager T H Ismail

7 Isolation And Identification of Vibrio parahemolyticus Recovered From Some Shellfish Marketed In Zagazig City

Iman IA Suelam, Amal RA Raslan and Mohamed EM Mohamed....

8 Bacteriological And Pathological Studies on Pneumonia in Lambs with Special references to inflammatory markers

Tharwat I A, Alkabbany MF and Abeer MA...

9 Histological And Ultrastructural Study On The Meibomian Gland Of Camel (Camelus dromedarius)

Balah AM, Abd El-Raheem WA, El-Baz AM and Nesma I El-naseery....

10 Bacteriological And Biochemical Studies On Pekin Duckling Infected With Pasteurella Miltocida With Trial For Treatment

Allam HH, Zaki R, H, Aly Salah ABS and Nagwa A Bahar... 
11 A Comparative Morphological Observations On The Preen (Uropygial) Glands Of Greese, Ducks And Young Pigeons

Nora Abdulaziz Saleh ALjalaud.

12 Occurrence of Enterotoxigenic $S$ aureus in Half-Cooked Chicken Products

Eman M Farid, Dalia A Salim and Amany N Dapgh....

13 Pharmacokinetic And Pharmacodynamic Studies Of Tulathromycin In Buffalo Calves

Zaki RH, Soad Mekawy and Eman M Z

14 Combined Antimicrobial Effects Against Gram Negative Bacteria Isolated From Broilers

Adel Attia Mohamed Ahmed, Ahmed Mahmoud Ahmed Hamouda, Gamal AbdElMoneim Elmowalid and Mohammed Fouad Fawzy

15 Studies on Biocoating Oral Immunization of Oreochromis niliticus Fingerlings with Aeromonas hydrophila Bacterin

Ahmed M. Abdel-Wahab.

16 Modulatory Role of Pre- And Post- Treatment Of Spirulina Platensis On Mitomycin C Drug Induced Genotoxicity And Pathological Changes In Ehrlich Ascites Carcinoma Bearing Mature Female Swiss Albino Mice

Magdy F Abou-El Fotoh, Nabela I El-Sharkawy, Samah Khalil and Mona M Ahmed...

17 Characterization Of Extended Spectrum $\beta$ - Lactamases In Enterobacteriaceae Atia AM and Salwa MM

18 Pathological Studies on Danofloxacin and Tilmicosin used for Treatment of Chronic respiratory Diseases in chicks

Moustafa S Abou El-Fetouh, Mohamed H Mohamed, Nahla AG Ahmed Refat and Nora M Elseddawy

19 Clinicopathological Studies On Broiler Exposed To High Environmental Temperature

Fakhry S Salem, Amany AM Abd Allah Sahar S Abd El-Hamied and Doaa IA Mostafa

20 The Effect Of Melissa Officinalis And Thymus vulgaris On Performance Parameters, Haematological Traits And Lipid Oxidation of Oreochromios Niloticus

Mahmoud R El and Eleraky Wafaa... 


\title{
PCR-based Differentiation Of Zoonotic Fascioliasis
}

\author{
Adel M Abdel-Aziz Newishy \\ Department of Zoonotic Disease, Faculty of Vet. Medicine, Benha University
}

\begin{abstract}
Out of 100 samples from slaughtered cattle of different ages were examined at Kalyobia province slaughterhouses Tukh center from October 2010 to October, 2011 in order to identify associated risk factors, $8 \%$ gave positive results (6 Fasciola hepatica and 2 Fasciola gigantica). Out of 100 stool samples examined from men occupationally contacts with cattle, $2 \%$ were
positives to fasciola hepatica only.
\end{abstract}

The histopathological examination of the cattle liver infested with fasciola species showed newly formed bile ductules with inflammatory cells infiltration and fibrosis associated with hyperplasia in the lining epithelium with polyps formation as well as the portal area showed severe fibrosis with inflammatory cells infiltration in both fasciola species lesions.

Regarding PCR technique, the using of Eael restriction endonuclease enzyme as a genetic marker for F.hepatica is greatly effective when the enzyme uniquely fragmented the SrRNA gene into two bands. That means PCR could help to evaluate the relative zoonotic potential of Fasciola hepatica and Fasciola gigantica, especially in those regions, which have huge increases in the

\section{INTRODUCTION}

Fascioliasis is an important disease caused by Fasciola hepatica and Fasciola gigantica. The distributions of both species overlap in many areas of Asia and Africa including Egypt. Fifty adult Fasciola worms were collected from livers of cattle slaughtered in slaughterhouses, Cairo, Egypt. They were subjected to morphological and metric assessment of external features of fresh adults, morphological and metric assessment of internal anatomy of stained mounted worms (1). Fascioliasis, an economically important disease of livestock, is largely caused by Fasciola hepatica in temperate climates and by Fasciola gigantica in tropical regions. The distributions of these two species overlap, however, in many countries of Asia and Africa (2), the disease is now recognised as an emerging food-borne zoonosis, with an estimated 17 million people infected with Fasciola world-wide, and 180 million at risk of such infection (3). The incidence of human infection appears to be increasing in rural regions. Diagnosis of the disease is achieved by detecting the ova either in feces or duodendal drainage or by imaging techniques proved to be the most useful method for confirming the diagnosis and follow-up of fascioliasis. Small, often peripheral, nonenhancing, hypodense nodules with tortuous, linear, branching tracts in CT scans, which decrease in size after successful therapy, are highly suggestive of the disease. Immature flukes can produce ectopic masses or abscesses in various locations and during the acute phase of the disease, other structures such as subcutaneous tissue, heart, lungs, pleura, abdominal wall, brain, cecum, epididymis, and stomach can be involved (4). In a particularly unusual report, direct peritoneal involvement with granuloma formation has been reported Eosinophilic reactions can be exhibited in the body as pleuritis and pericarditis (5). Here, we present an extremely unusual radiologic incident of fascioliasis involving multiple 


\section{MATERIAL AND METHODS}

100 liver samples were collected from slaughtered cattle in the Tukh center of Kalyobia province slaughterhouses (6). Also 100 stool samples were collected from individuals occupationally in contact with cattle including apparently healthy and clinically diseased in the same location.

\section{Examination of human stool samples}

Human fecal samples were directly obtained from the rectum or immediately after defecation and placed in polyethylene bags, closed well labeled with a serial number, locality and date of collection. Closed fecal polyethylene bags were placed in plastic bags, and then transported to the laboratory with a minimum of delay (7).

\section{Direct smear method (8).}

\section{Kato thick smear}

Approximately $1 \mathrm{~g}$ of feces is placed on filter paper ( $5 \mathrm{~cm}$ square) and pressed through a 100 mesh (150 um pore size) sieve. The sieved stool sample, containing helminthes eggs, but no particles larger than the sieve mesh size, is scraped off the wire surface of the sieve with the edge of a microscope slide and packed into the head of a disposable syringe, previously calibrated to deliver $30 \mathrm{mg}$. This amount is put on a slide, which is then inverted and pressed firmly down on a thick glass cover slip. The diameter of the fecal smear is usually about 25 $\mathrm{mm}$. The slide should be examined before drying out occurs within 2 hours. The efficacy of the modified technique was estimated by attempting to retrieve known numbers of eggs that had been added to a stool from an uninfected subject. These eggs were obtained from heavily infested human stools by sieving, sedimentation, washing, and centrifugation of the emulsified stool. The number of eggs in a drop of suspension placed on a slide was counted under the microscope. One gram of human stool negative for helminthes then added to the slide, and the eggs and stool were thoroughly mixed. Six $30 \mathrm{-mg}$ amounts were taken according to the method outlined above, and the eggs in each sample were counted under the microscope (x 40) (9).

Examination of samples from slaughtered cattle

The liver samples were obtained thorough routine post mortem examination of slaughtered animals. Data recorded from each animal included: species, owner's name and the time of sampling. Thus, gross inspection was done on each slaughtered animal including also the whole carcass and the internal organs (10).

Histopatholgical examination of naturally infested tissues

Samples from cattle liver were collected and fixed in neutral buffered formalin 10\%, washed in tap water overnight and exposed to ascending concentrations of ethanol (100\%), cleared in xylene and embedded in paraffin. Sections of the tissues (4-5 $\mu$ thick) were prepared and stained with Hematoxylin and Eosin for subsequent histopathological examination (11).

\section{Characterization of Fasciola species by PCR}

Determination of genomic DNA

The total DNA of the two species (Fasciola hepatica and Fasciola gigantica) was extracted using the UNSET lysis solution (12). One $\mu \mathrm{l}$ of the suspended pellet was checked by $0.8 \%$ gel electrophoresis for the presence of DNA.

Nuclear subunit ribosomal RNA (Sr RNA) gene detection

The nuclear small Sr RNA genes of the two species of Fasciola were detected by using the following primers:

\section{SSU1 (5, - CGACTGGTTGATCCTGCCAGTAG - 3,)}

\section{SSU2 (3, - TCCTGATCCTTCTCAGGTTCAC - 5, )}

The program of PCR for amplification of nuclear SrRNA was 30 cycles for 1 minute at $94^{\circ} \mathrm{C}, 2$ minutes at $45^{\circ} \mathrm{C}$ and 3 minutes at $72^{\circ} \mathrm{C}$ (13).

Restriction fragment length polymorphisms profiles

Restriction endonuclease represented by Eael (Roche Applied Science) was used to 
identify and differentiate the nuclear small subunit ribosomal RNA (SrRNA) gene of the two species of Fasciola. For each digestion reaction, one $\mu \mathrm{l}$ was used together with $1.2 \mu \mathrm{l}$ of the particular enzyme buffer for a final volume of $12.2 \mu \mathrm{l}$. The digestion was carried out for $3.5 \mathrm{hrs}$ at $37^{\circ} \mathrm{C}$ and the digestion products were evaluated on $2 \%$ TE agarose gels and stained with ethidium bromide.
Accordingly, the restriction patterns were detected upon ultra violet transillumination and photographed.

Analysis of PCR amplified products Accurately, PCR amplified products were analysed by agarose gel electrophoresis on $1.4 \%$ gel containing ethidium bromide dye $(0.5$ $\mu \mathrm{l} / \mathrm{ml}$ )

\section{RESULTS}

Table 1. Infectious rate of Fasciola hepatica and Fasciola gigantica in Cattle in Kaloubia Province: Numbers of examined animals (100)

Fasciola species Fasciola hepatica Fasciolagigantica Total Numbers

Infectious rate

$6 \%$

$2 \%$

$8 \%$

Table 2. Infectious rate of fascioliasis in human in Kaloubia Province Numbers of examined human (100)

\begin{tabular}{ccc}
\hline Species & $\begin{array}{c}\text { Numbers of examined } \\
\text { Human }\end{array}$ & Infectious rate \\
\hline Human & 100 & $2 \%$ \\
\hline
\end{tabular}




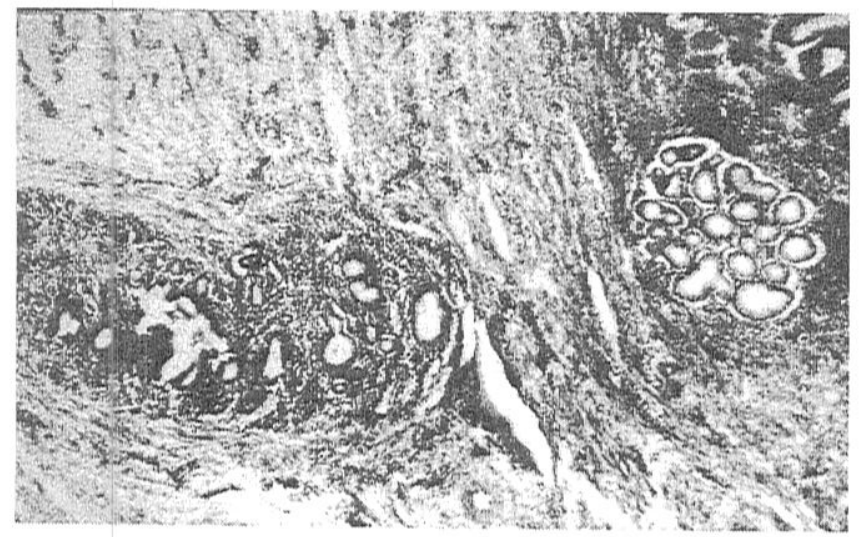

Fig. 1. Electromicrograph of liver of cattle showing fibrosis in the wall of bile duct with inflammatory cells infiltration and newly formed bile ductules (a)

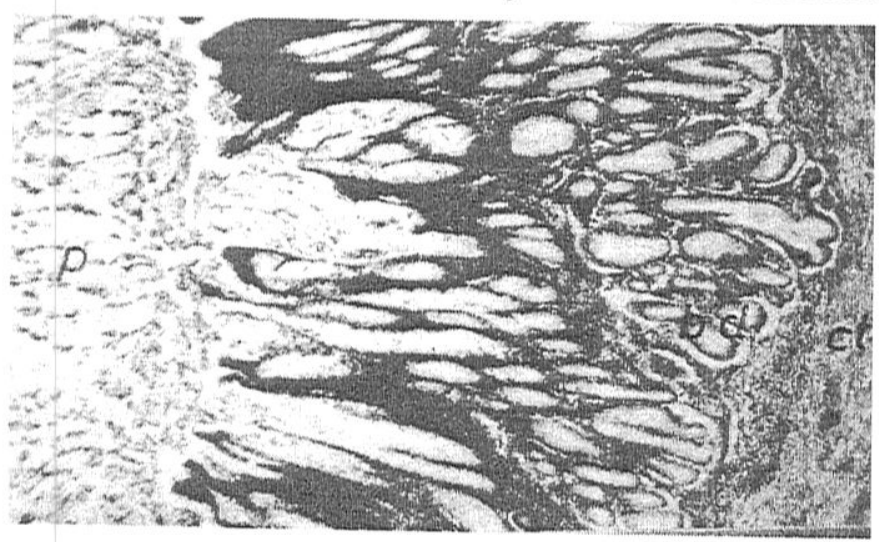

Fig. 2. Electromicrograph of liver of cattle showing part of the parasite embedded in lumen of bile ducts (b) associated with hyperplasia in the lining epithelium of bile ducts (bd) with polyps formation and periductal inflammatory cells infiltration (ct)

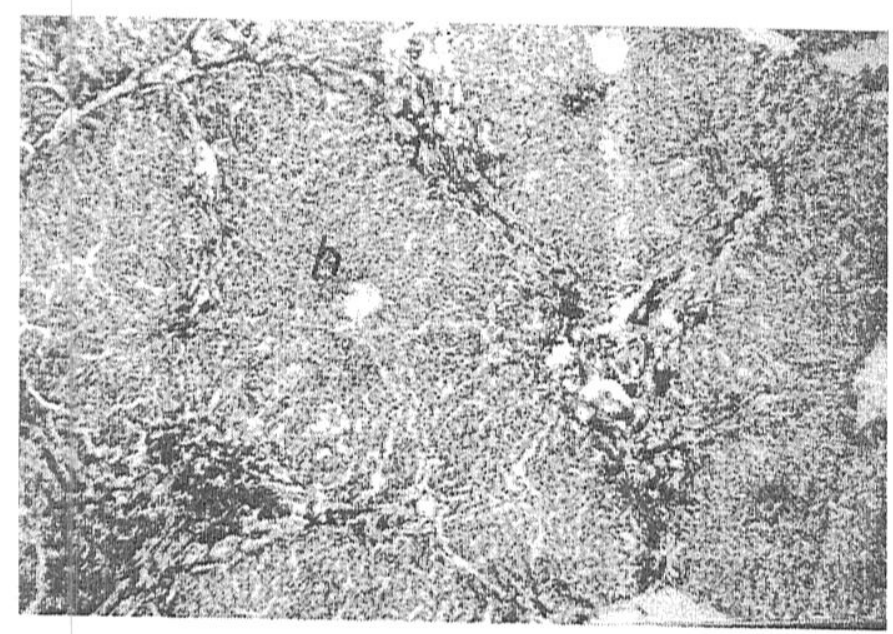

Fig. 3. Electromicrograph of liver of cattle showing fibrosis (f) arising from the portal area dividing the hepatic parenchyma (h) into lobules 


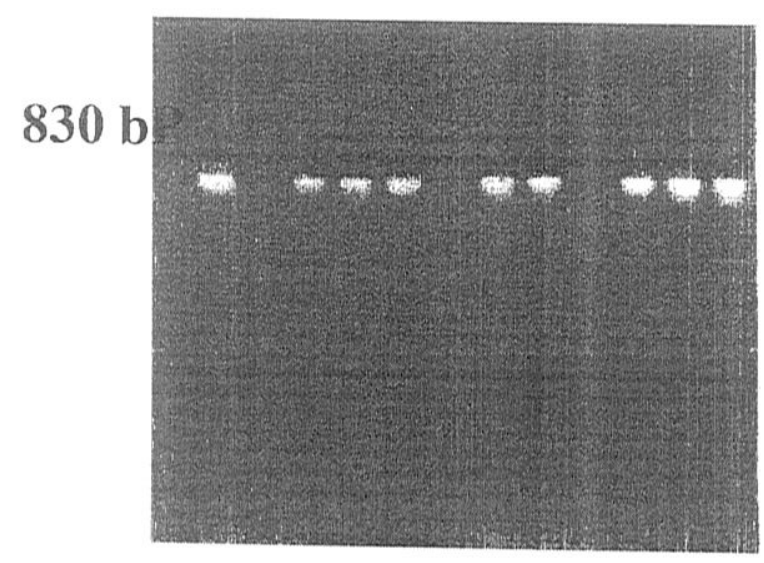

Fig. 4. Gell electrophoresis of PCR amplified products using specific agarose primer for characterization of Fasciola hepatica

\section{DISCUSSION}

The results of postmortem examinations of Fasciola hepatica and Fasciola gigantic are represented in Table 1. Infections among slaughtered cattle in Kaloubia Province Tukh center slaughterhouses revealed that out of 100 examined cattle, 6 were infected with $F$. hepatica and 2 with $F$ gigantica, with an infectious rate of $6 \%$ and $2 \%$ respectively (Table 1). This may be due to immune suppression and / or associated with eating of freshwater plants that potentially carry attached metacercariae $(14,15)$.

Table 2 shows the coprologic examinations of fascioliasis, infections among human in Kaloubia Province, revealed that out of 100 examined human stool in both sex, 2 were positives with infection rate $2 \%$, the low infectious rates may be due to developed sewerage system, socio-economic level and education. Eating raw vegetable salads is a significant risk factor through which families may acquire the infection in endemic areas. A finding that similar to previous study (3).

From the histopathological examination of the liver infected with Fasciola species we observed that the portal area showed newly formed bile ductules with inflammatory cells infiltration and fibrosis (Figure 1). Part of the parasite was embedded in the lumen of the bile ducts associated with hyperplasia in the lining epithelium with polyps formation and periductal inflammatory cells infiltration (Figure 2). The fibroblasts were originated from the portal areas and dividing the hepatic parenchyma into lobules (Figure 3). The Histopathological examination of the postmortem examination to the liver of infected animals did not differentiate between the two Fasciola species. These results come in accordance with those previously reported (16,17).

Figure 4 illustrate the results of the application of PCR for differentiation of the two Fasciola species in man and cattle by using specific primers of $F$.hepatica. These results indicated that 8 samples had positive bands related to $F$. hepatica and 2 negative bands representing $F$. gigantica. Consequently, the using of Eael restriction endonuclease enzyme as a genetic marker for F. hepatica was greatly effective when the enzyme uniquely fragmented the SrRNA gene into two bands without digesting the gene of $F$. gigantica. 
The current results were nearly similar with those obtained in several studies in China $(18,19)$.

On the other hand, simple and rapid PCR RFLP are used to distinguish $F$. hepatica from $F$. gigantica, based on a 618 bp long sequence of 28 SrRNA gene recently obtained from liver fluke populations, and found few nucleotide differences between both Fasciola species and no intraspecific variation between each species (20). However, a genetic variation between $F$. gigantica and $F$. hepatica with amplification fragment based on a 400-500 bp was described (21).

Accordingly, one can confirm that PCR is simple, rapid and accurate tool for differentiation of the two species of Fasciola as compared with those of morphological, pathological or immunological techniques.

Infection in humans is often but not always associated with endemic disease in livestock, and there is a need to investigate the role of domestic and wild animals as 'reservoir hosts' for human infection. The PCR-based assays described here clearly have a range of potential epidemiological applications, particularly where Fasciola hepatica and Fasciola gigantea co-exist (3).

\section{CONCLUSION}

We can conclude that human fascioliasis is found in a high proportion to the relatives of index cases, and this should be taken into account when fascioliasis is detected; it is usually present in most members of a family. Eating raw vegetable salads is a significant risk factor through which families may acquire the infection in endemic areas. It is recommended that patients presenting abdominal pain and low to high eosinophilia, who have recently visited an area endemic for $F$. hepatica, should be carefully studied so as to rule out this parasitosis and the study could be expanded to include other travel companions or family members as well. In endemic areas, adult are the most affected agegroup, and the adult groups usually present the highest infection rates, which is consistent with our results. Apparently, good hygienic habits decrease the risk of acquiring fascioliasis. People with good hygienic habits may be less likely to contract the infection, may having less contact with the contaminated environment than those with poor hygienic habits.

\section{REFERENCES}

1.Hoda $H$, Abeer $M A$, Naglaa said $M$, Waheed $M A$ and Abeer $S A$ (2012): Molecular, biochemical, and morphometric characterization of Fasciola species potentially causing zoonotic disease in Egypt Parasitology Research Volume 111, Number 3 (2012), 1103-1111, DOI: $10.1007 / \mathrm{s} 00436-012-2938-2$.

2.Mas-Coma S (2005): Epidemiology of fascioliasis in human endemic areas. J. Helminthol., 79: 207-216.

\section{Mas-Coma M S , Esteban $J G$ and Bargues} $M D$ (1999): Epidemiology of human fascioliasis: a review and proposed new classification. Bull. Wld. Hlth. Org., 77: 340-346.

4.Pulpeiro $J R$, Armesto $V$, Varela $J$, Corredoipa $J$ (1991):Fascioliasis: findings in 15 patients. Br J Radiol, 64:798-801.

\section{Haçarız $O$, Sayers $G$ and Baykal A $T$} (2012): A proteomic approach to investigate the distribution and abundance of surface and internal Fasciola hepatica proteins during the chronic stage of natural liver fluke infection in cattle. J Proteome Res. 6;11(7):3592-604.

6.Faust $E C$, Russell $P \quad E$ and Jung $R C$ (1970): Clinical Parasitology, $8^{\text {th }}$ ed. Lea \& Febiger, Philadelphia, 64: 67.

7.Garcia L S and Bruckner D A (1993): Macroscopic and Microscopic examination 
of Fecal Specimens. Diagnostic Medical Parasitology. $2^{\text {nd }}$ edition. Edited by: Garcia LS, Bruckner DA. Washington. American Society for Microbiology: 501-535.

8.El-Rahimy H H, Mahgoub A M, El-Gebaly $N S$, Mousa W M and Antably A S (2012): Molecular, biochemical, and morphometric characterization of Fasciola species potentially causing zoonotic disease in Egypt. Parasitol Res. Sep;111(3):110311. Epub 26.

9.Ekong P S, Juryit Dika $R$ N M, Nguku P and Musenero $M$ (2012): Prevalence and risk factors for zoonotic helminth infection among humans and animals - Jos, Nigeria, 2005-2009. Pan Afr Med J. ;12:6. Epub 12.

10.Rapsch C, Schweizer $G$, Grimm $F$, Kohler $L$, Bauer $C$, Deplazes $P$ and Braun $U$ and Torgerson $P R$ (2006): Estimating the true prevalence of Fasciola hepatica in cattle slaughtered in Switzerland in the absence of an absolute diagnostic test. Int J Parasitol. 2006 Sep;36(10-11):1153-8.

11.Banchroft J D, Stevens $A$ and Turner D $R$ (1996): Theory and practice of histological techniques. Fourth Ed. Churchil Living stone, New york.

12.Hugo $A$, Stewart $V$, Gast $R$ and Byars $T$ (1992) : Purifiation of $\mathrm{mt}-\mathrm{DNA}$ using PCR procedure. In "Protocol in protozoology" Lee, J. and Soldo, A. Eds, Eoc. Protozoologist, Lawrence pp. 71-74.

\section{Stohard $J$ and Rollinson D (1997): Molecular characterization of Bulinus globosus and Fasciola in Zanziban and an investigation of their roles in the epidemiology. Sco. Trop. Med. Hyg., 91: 353-357.}

\section{Maco $V$, Marcos LA and Terashima $A$ (2002): Fas2-ELISA y la técnica de}

sedimentación rápida modificada por Lumbreras en el diagnóstico de la infección por Fasciola hepatica. Rev. méd. Herediana, 13: 49-57.

15.Esteban J G, Gonzalez $C$ and Bargues MD (2002): High fascioliasis infection in children linked to a man-made irrigation zone in Perú. Trop. Med. Int. Hlth, 7: 339348.

16 Duff J P , Maxwell A J and Claxton J R (1999): Chronic and fatel fascioliasis in llamas in the U.K. Vet. Rec. 145 (11): 315 316.

17.Ansari-Lari M and Moazzeni M (2006) A retrospective survey of liver fluke disease in livestock based on abattoir data in Shiraz, south of Iran. Preventive. Vet. Med., 73 (1): 93-96.

18.Huang $W Y$, Wang $H B$ and Zhu $C R$ (2004): Characterization of Fasciola species from Mainland China by ITS-2 ribosomal DNA sequence. Vet. Parasitol ., $120(1-2): 75-83$.

19.Lin $R Q$, Dong $S J$, Nie $K$, Wang $C R$, Song $H Q, L i A X$, Huang $W Y$ and Zhu $X Q$ (2007): Sequence analysis of the first internal transcribed spacer of rDNA supports the existence of the intermediate Fasciola between F. hepatica and F. gigantica in mainland China. Parasitol Res., 101(3): 813-817.

20.Marcilla A, Bargues $M D$ and Mas Coma $S$ (2002): A PCR - RFLP assay for the distinction between F. hepatica and F. gigantica. Mol Cell Probes., 16 (5): 327 333.

21.Ramadan N I and Saber L M (2004): Detection of genetic variability in non human isolates of $F$. hepatica and $F$. gigantica by the RAPD-PCR technique. J. Egypt. Soc. Parasitol., 34 (2): 679-689. 


\title{
الملخص المربي
}

\section{التمايز للمتورقة الكبدية المشتركة بأستخدام أختبار PCR}

\author{
قسم الأمر اض المشتركة - كلبة الطب البزيز نويشى - جامعة بنها
}

من . . 1 عينة من الماشية من مختلف الأعمار المذبوحة في مسالخ مركز طوخ بمدافظة القليوبية

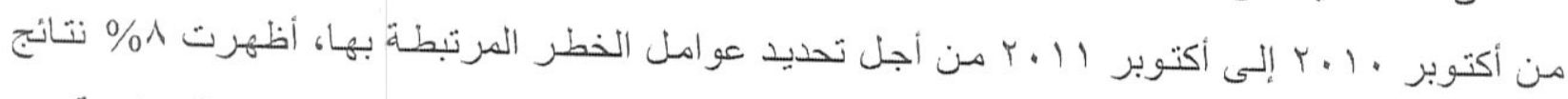

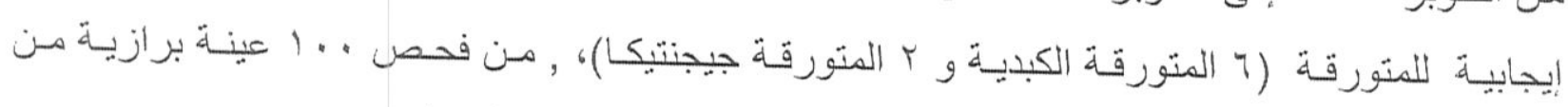

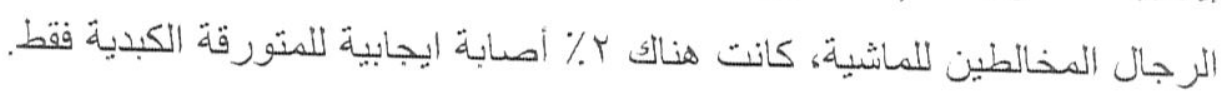

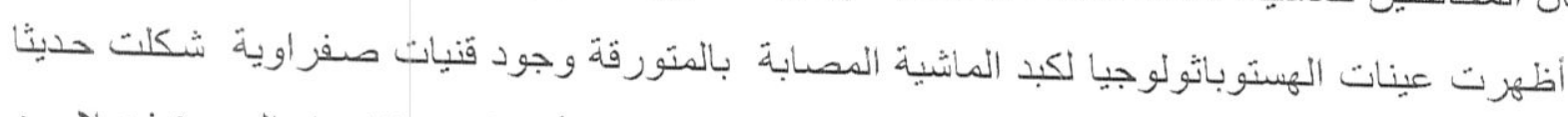

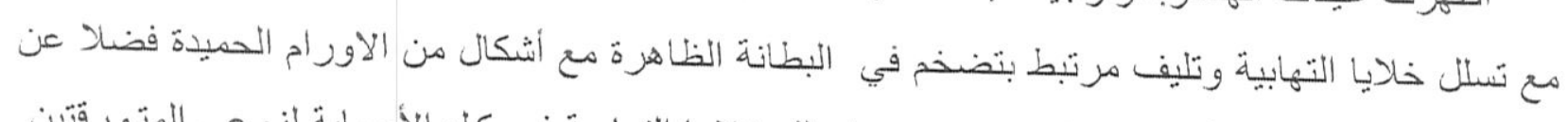
ان منطقة مدخل الكبد أظهرت تليف شديد مع تسلل خلايـا التهابية في كل الأصسابة لنو عى المتورقتنين.

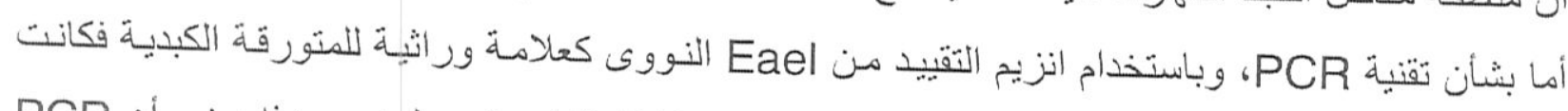

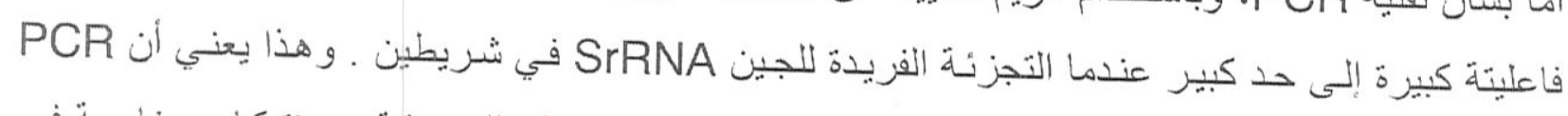

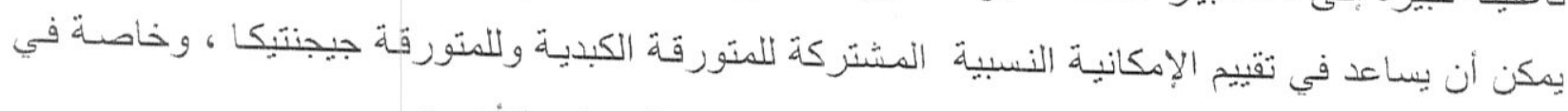
تلك المناطق التي بزيد فيها حدوث داء المنورقات للإنسان في السنوات الأخيرة. 